Yu. A. Azev, ${ }^{*}$ O. S. Koptyaeva, O.S. Eltsov, Yu. A. Yakovleva, T. A. Pospelova Ural Federal University 620002, 19 Mira St., Ekaterinburg, Russian Federation *email: azural@yandex.ru

\title{
New pathways for the synthesis of indolyl-containing quinazoline trifluoroacetohydrazides
}

The reactions of indole-3-carbaldehyde arylhydrazones with quinazoline in TFA proceed at the 7 ' position of the aryl part of the hydrazone molecule to form $\sigma$-adducts of quinazoline trifluoroacetohydrazides.

Keywords: arylhydrazones; indole-3-carboxaldehydes; C,C-coupling; trifluoroacetyl quinazoline hydrazides.

Received: 19.08.2020. Accepted: 28.09.2020. Published: 07.10.2020.

(c) Yu. A. Azev, 0. S. Koptyaeva, 0. S. Eltsov, Yu. A. Yakovleva, T. A. Pospelova, 2020

\section{Introduction}

It is known that the quinazoline core is part of natural alkaloids $[1,2]$. Among the quinazoline derivatives, compounds have been identified that have various types of biological activity, including antimicrobial, antiallergic, hypotonic, and antiviral [3]. Quinazoline derivatives have been synthesized, which have shown antitumor [4] and radioprotective activity [5].

The addition of $\mathrm{C}$-nucleophiles to 3-methylquinazolinium iodide with the formation of 4-substituted 3,4-dihydroquinazolines has been reported [6]. It is also known that unsubstituted quinazoline reacts with indole, 3-methyl-1-phenylpyrazolone-5, 1,3-dimethylbarbituric acid, and pyrogallol in the presence of acid to form 4 - $\sigma$-adducts [7]. Examples of arylation of quinazoline with 1,3,5-trimethoxybenzene, 1-(4-methoxybenzylidene) - 2-phenylhydrazine, and o-phenylenediamine derivatives have been described [8].

To create effective drugs based on quinazoline, it is important to be able to change substituents (pharmacophoric fragments) in the structure of the compound. Theoretically, this will allow to affect their physicochemical properties (hydrophilicity, lipophilicity, etc.), changing their bioavailability and activity.

Indole is part of tryptophan and its metabolites and this one is also present in a number of natural alkaloids and antibiotics [9]. Indole derivatives exhibit antitumor, antiviral, anti-inflammatory, antidepressant, and other types of activity [10].

This work is a continuation of research related to the development of methods for the synthesis of biologically active derivatives of quinazoline [7]. It should be noted that within the framework of this direction, atomic-economical reactions corresponding to the principles of green chemistry are a particular value [11]. This type of interactions includes nucleophilic reactions of $\mathrm{C}, \mathrm{C}$ coupling under conditions of acid catalysis, which proceed without using of metal catalysts and are theoretically waste-free $[12,13]$. 


\section{Experimental section}

Unless otherwise indicated, all common reagents and solvents were used from commercial suppliers without further purification.

The reaction progress and purity of the obtained compounds were controlled by TLC method on Sorbfil UV-254 plates, using visualization under UV light. Melting points were determined on a Stuart SMP10 melting point apparatus.

$1 \mathrm{H}, 13 \mathrm{C}$ and 19F NMR spectra were acquired on Bruker Avance-400 and Bruker Avance NEO - 600 spectrometers in DMSO-d6 solutions, using TMS as internal reference for $1 \mathrm{H}$ and $13 \mathrm{C} \mathrm{NMR}$ or $\mathrm{CFCl}^{3}$ for $19 \mathrm{~F}$ NMR. Mass-spectra (EI, $70 \mathrm{eV}$ ) were recorded on MicrOTOF-Q instrument (Bruker Daltonics) at $250^{\circ} \mathrm{C}$.

The general method for the reaction of indole carbaldehyde $\mathbf{1}$ with hydrazines $2 a-2 d$

2-Methyl-1H-indole-3-carbaldehyde $\mathbf{1}$ $(0.5 \mathrm{mmol})$ was dissolved in ethanol $(3 \mathrm{ml})$. Then this solution was added to mixture of the corresponding hydrazine 2 and hydrochloric acid $(0.02 \mathrm{ml})$ in water $(3.0 \mathrm{ml})$. The resulting mixture was refluxed for 5-10 minutes and then was cooled. The resulting solid was filter off and dried. The crude hydrazones were used directly in the next step without additional purification.

Spectral data for hydrazones $\mathbf{3 a - c}$ were described earlier [14].

2-Methyl-3-\{[2-(4-methylphenyl) hydrazono] methyl $\}$ - $\mathbf{H}$-indole (3d)

Yield 55\%, mp $185-186^{\circ} \mathrm{C} .{ }^{1} \mathrm{H}$ NMR spectrum $\left(600 \mathrm{MHz}, \mathrm{DMSO}-d_{6}\right), \delta$, ppm: $2.21 \mathrm{~s}\left(3 \mathrm{H}, \mathrm{CH}_{3}\right), 2.48 \mathrm{~s}\left(3 \mathrm{H}, \mathrm{C}^{2} \mathrm{CH}_{3}\right)$, $6.93 \mathrm{~d}\left(2 \mathrm{H}, J 8.4 \mathrm{~Hz}, \mathrm{H}_{0}\right), 7.02 \mathrm{~d}(2 \mathrm{H}, J$ $\left.8.4 \mathrm{~Hz}, \mathrm{H}_{m}\right), 7.07-7.11 \mathrm{~m}\left(2 \mathrm{H}, \mathrm{H}^{5}\right.$ and $\left.\mathrm{H}^{6}\right), 7.30 \mathrm{~m}\left(1 \mathrm{H}, \mathrm{H}^{7}\right), 8.12-8.15 \mathrm{~m}(2 \mathrm{H}$,
$\mathrm{H}^{1}$ and $\left.\mathrm{H}^{4}\right), 9.61$ br.s $\left(1 \mathrm{H}, \mathrm{N}^{3} \mathrm{H}\right), 11.19 \mathrm{~s}$ $\left(1 \mathrm{H}, \mathrm{N}^{1} \mathrm{H}\right) . \mathrm{MS}, \mathrm{m} / \mathrm{z}\left(\mathrm{I}_{\mathrm{rel}} \%\right): 263\left(\mathrm{M}^{+}, 100\right)$.

2-Methyl-3-[(2-phenylhydrazinyl) methyl]-1H-indole (3e). Yield 59\%, m. p. $192-193{ }^{\circ} \mathrm{C} .{ }^{1} \mathrm{H}$ NMR spectrum $(600$ $\left.\mathrm{MHz}, \mathrm{DMSO}-d_{6}\right), \delta$, ppm: $2.49 \mathrm{~s}(3 \mathrm{H}$, $\left.\mathrm{CH}_{3}\right), 6.67$ t.t $\left(1 \mathrm{H}, J 7.3,1.2 \mathrm{~Hz}, \mathrm{H}_{p}\right), 7.03$ d.d $\left(2 \mathrm{H}, J 8.5,1.2 \mathrm{~Hz}, \mathrm{H}_{0}\right), 7.08-7.12 \mathrm{~m}$ $\left(2 \mathrm{H}, \mathrm{H}^{5}, \mathrm{H}^{6}\right), 7.21$ d.d $(2 \mathrm{H}, J 8.5,7.3 \mathrm{~Hz}$, $\left.\mathrm{H}_{m}\right), 7.31 \mathrm{~m}\left(1 \mathrm{H}, \mathrm{H}^{7}\right), 8.15 \mathrm{~m}\left(1 \mathrm{H}, \mathrm{H}^{4}\right)$, $8.17 \mathrm{c}\left(1 \mathrm{H}, \mathrm{H}^{1}\right), 9.78$ br.s $\left(1 \mathrm{H}, \mathrm{N}^{3} \mathrm{H}\right)$, $11.23 \mathrm{~s}\left(1 \mathrm{H}, \mathrm{N}^{1} \mathrm{H}\right) .{ }^{13} \mathrm{C}$ NMR spectrum (151 MHz, DMSO- $\left.d_{6}\right), \delta$, ppm: 136.06 $\left(C^{2}\right), 118.04\left(C^{3}\right), 129.91\left(C^{3 a}\right), 130.99$ $\left(C^{4}\right), 127.76\left(C^{5}\right), 127.49\left(C^{6}\right), 127.78$ $\left(C^{7}\right), 132.84\left(C^{7 a}\right), 139.22\left(C^{1}\right), 139.44$ $\left(\mathrm{C}_{\mathrm{i}}\right), 124.4\left(\mathrm{C}_{o}\right), 129.27\left(\mathrm{C}_{m}\right), 127.67\left(\mathrm{C}_{\mathrm{p}}\right)$, $115.98\left(\mathrm{CF}_{3}\right), 155.28(\mathrm{C}=\mathrm{O}) .{ }^{15} \mathrm{~N}$ NMR spectrum $\left(61 \mathrm{MHz}, \mathrm{DMSO}-d_{6}\right), \delta$, ppm: $126.8\left(\mathrm{~N}^{1}\right), 305\left(\mathrm{~N}^{3}\right), 218.5\left(\mathrm{~N}^{3}\right) . \mathrm{MS}, \mathrm{m} / \mathrm{z}$ $\left(\mathrm{I}_{\mathrm{rel}} \%\right): 249\left(\mathrm{M}^{+}, 100\right)$.

The general method for the reaction of hydrazones $3 \boldsymbol{d}$-3e with quinazoline 4

A mixture of quinazoline $4(0.5 \mathrm{mmol})$ and the corresponding hydrazone $\mathbf{3 d}$,e in TFA $(3.0 \mathrm{ml})$ was refluxed for $65-70$ h. The solvent was removed under reduced pressure. Water $(2.0 \mathrm{ml})$ was added to the residue; the solid was filtered off. The resulting product $\mathbf{6 a} \mathbf{a}, \mathbf{b}$ was analytically pure and no additional purification was required.

4-(4-(2-((1H-indol-3-yl) methylene) - 1-(2,2,2-trifluoroacetyl)hydrazinyl)phenyl) - 1,4-dihydroquinazolinium-32,2,2- trifluoroacetate (6a). Yield 51\%, m.p. $112-113{ }^{\circ} \mathrm{C} .{ }^{1} \mathrm{H}$ NMR spectrum $\left(600 \mathrm{MHz}, \mathrm{DMSO}-d_{6}\right), \delta$, ppm: $6.24 \mathrm{~s}\left(1 \mathrm{H}, \mathrm{H}^{4^{\prime \prime}}\right), 7.07 \mathrm{~d}(1 \mathrm{H}, J 7.4 \mathrm{~Hz}$, $\left.\mathrm{H}^{5^{\prime \prime}}\right), 7.20-7.24 \mathrm{~m}\left(2 \mathrm{H}, \mathrm{H}^{6^{\prime \prime}}, \mathrm{H}^{7^{7 \prime}}\right), 7.37 \mathrm{t}$ $\left(1 \mathrm{H}, J 7.7 \mathrm{~Hz}, 1 \mathrm{H}, \mathrm{H}^{5}\right), 7.41 \mathrm{~d}(1 \mathrm{H}, J 6.7$ $\left.\mathrm{Hz}, \mathrm{H}^{4}\right), 7.43-7.45 \mathrm{~m}\left(2 \mathrm{H}, \mathrm{H}^{6,7}\right), 7.61 \mathrm{~d}$ 
$\left(2 \mathrm{H}, J 8.4 \mathrm{~Hz}, \mathrm{H}^{5^{\prime}}\right), 7.69 \mathrm{~d}(2 \mathrm{H}, J 7.6 \mathrm{~Hz}$, $\left.\mathrm{H}^{8^{\prime \prime}}\right), 7.92 \mathrm{~d}\left(2 \mathrm{H}, J 8.4\right.$ Гц, $\left.\mathrm{H}^{6}\right), 7.98 \mathrm{~s}(1 \mathrm{H}$, $\left.\mathrm{H}^{1^{\prime}}\right), 8.57 \mathrm{~s}\left(1 \mathrm{H}, \mathrm{H}^{2 \prime}\right), 8.80 \mathrm{~s}\left(1 \mathrm{H}, \mathrm{H}^{2}\right)$, $11.18 \mathrm{~s}\left(2 \mathrm{H}, \mathrm{N}^{1} \mathrm{H}, \mathrm{N}^{3 "} \mathrm{H}\right), 12.37 \mathrm{~s}(1 \mathrm{H}$, $\mathrm{COOH}) .13 \mathrm{C}$ NMR spectrum $(151 \mathrm{MHz}$, DMSO- $\left.d_{6}\right), \delta$, ppm: $54.61\left(\mathrm{C}^{4 \prime}\right), 116.39 \mathrm{q}$ $\left(1 \mathrm{C}, \mathrm{J} 288.7 \mathrm{~Hz}, \mathrm{CF}_{3}\right), 117.59\left(\mathrm{C}^{8 \prime}\right), 119.17$ $\left(C^{3}\right), 121,42\left(C^{6}\right), 122.42\left(C^{4 a}\right), 126.86$ $\left(C^{7}\right), 127.83\left(C^{6 ”}\right), 128.22\left(C^{7^{\prime}}\right), 128.60$ $\left(C^{5}\right), 128.73\left(C^{5^{\prime \prime}}\right), 129.34\left(C^{7^{\prime \prime}}\right), 129.48$ $\left(C^{4}\right), 129.82\left(C^{8 a}\right), 130.07\left(C^{3 a}\right), 131.90$ $\left(C^{7 a}\right), 132.0\left(C^{4}\right), 139.89\left(C^{7}\right), 140.54$ $\left(C^{5}\right), 141.1\left(C^{6}\right), 149.14\left(C^{2 "}\right), 156.00 \mathrm{q}$ $\left(1 \mathrm{C},{ }^{2} J 36.3 \mathrm{~Hz}, \mathrm{COCF}_{3}\right), 158.44 \mathrm{q}(1 \mathrm{C}$, $\left.{ }^{2} J 30.7 \mathrm{~Hz}, \mathrm{COOH}\right) .{ }^{19} \mathrm{~F}$ NMR spectrum $\left(376 \mathrm{MHz}, \mathrm{DMSO}-d_{6}\right), \delta$, ppm: -73.50 , 74.12. ${ }^{15} \mathrm{~N}$ NMR spectrum $(61 \mathrm{MHz}$, DMSO- $\left.d_{6}\right), \delta$, ppm: $126.9\left(\mathrm{~N}^{1^{\prime \prime}}, \mathrm{N}^{3 "}\right), 218.6$ $\left(\mathrm{N}^{1}, \mathrm{~N}^{3}\right), 301.6\left(\mathrm{~N}^{2}\right)$. MS, $\mathrm{m} / \mathrm{z}\left(\mathrm{I}_{\text {rel }}, \%\right): 461$ $\left(\mathrm{M}^{+}, 20\right), 369$ (11), 131 (100).

4-(4-(2-((2-methyl-1H-indol-3-yl) methylene) - 1-(2,2,2-trifluoroacetyl) hydrazinyl)phenyl) - 1,4-dihydroquinazolinium-3 2, 2,2-trifluoroacetate (6b). Yield 55\%, m.p. $121-122{ }^{\circ} \mathrm{C} .{ }^{1} \mathrm{H}$ NMR spectrum (600 MHz, DMSO- $\left.d_{6}\right), \delta$, ppm: $2.21 \mathrm{~s}\left(3 \mathrm{H}, \mathrm{CH}_{3}\right), 6.28 \mathrm{~s}\left(1 \mathrm{H}, \mathrm{H}^{4 "}\right)$, $7.11 \mathrm{~d}\left(1 \mathrm{H}, \mathrm{CH}_{\mathrm{ar}}\right), 7.24 \mathrm{~m}\left(2 \mathrm{H}, \mathrm{CH}_{\mathrm{ar}}\right), 7.38$ $\mathrm{t}\left(1 \mathrm{H}, J 7.7 \mathrm{~Hz}, \mathrm{CH}_{\mathrm{ar}}\right), 7.44 \mathrm{~s}\left(5 \mathrm{H}, 4 \mathrm{CH}_{\text {ind, }}\right.$ $\left.\mathrm{CH}_{\mathrm{ar}}\right), 7.63 \mathrm{~s}\left(3 \mathrm{H}, \mathrm{CH}_{\mathrm{ar}}\right), 7.64 \mathrm{~s}\left(1 \mathrm{H}, \mathrm{H}^{{ }^{\prime}}\right)$, $8.57 \mathrm{~s}\left(1 \mathrm{H}, \mathrm{H}^{2 "}\right), 11.03 \mathrm{~m}(2 \mathrm{H}, \mathrm{NH}), 12.37$ br.s (1H, COOH). 13C NMR spectrum (151 MHz, DMSO- $d_{6}$ ), $\delta$, ppm: 11.34 $\left(\mathrm{CH}_{3}\right), 55.96\left(\mathrm{C}^{4 \prime}\right), 115.33 \mathrm{q}(1 \mathrm{C}, J 147.38$ $\left.\mathrm{Hz}, \mathrm{CF}_{3}\right), 118.06\left(\mathrm{C}^{8 ”}\right), 119.17\left(\mathrm{C}^{3}\right), 123.08$ $\left(C^{6^{3}}\right), 124.11\left(\mathrm{C}^{4 \mathrm{a}}\right), 124.53\left(\mathrm{C}^{7}\right), 127.50$ $\left(C^{6^{\prime \prime}}\right), 127.67\left(C^{7^{\prime}}\right), 127.74\left(C^{5^{\prime}}\right), 127.78$ $\left(C^{5 "}\right), 127.95\left(C^{7 ”}\right), 129.85\left(C^{8 a}\right), 130.97$ $\left(C^{4}\right), 132.86\left(C^{7 a}\right), 136.05\left(C^{3 a}\right), 138.50$ $\left(\mathrm{C}^{4}\right), 138.87\left(\mathrm{C}^{7}\right), 138.87\left(\mathrm{C}^{5}\right), 144.98$ $\left(C^{6}\right), 146.48\left(C^{2 \prime}\right), 155.30 \mathrm{q}(1 \mathrm{C}, J 36.5 \mathrm{~Hz}$, $\left.\mathrm{COCF}_{3}\right), 158.17 \mathrm{q}\left(1 \mathrm{C},{ }^{2} \mathrm{~J} 30.9 \mathrm{~Hz}, \mathrm{COOH}\right)$. ${ }^{19} \mathrm{~F}$ NMR spectrum $(376 \mathrm{MHz}$, DMSO- $\left.-d_{6}\right), \delta$, ppm: $-73.72,-74.07 . \mathrm{MS}, \mathrm{m} / \mathrm{z}$ $\left(\mathrm{I}_{\text {rel }}, \%\right): 475\left(\mathrm{M}^{+}, 27\right), 345(25), 131$ (100).

General procedure for the synthesis of compounds $7 \boldsymbol{a}, \boldsymbol{b}$

$0.3 \mathrm{Mmol}$ of corresponding hydrazone 3d,e was heated in TFA for 45-50 h. The solvent was removed under reduced pressure. The solid residue was treated with water $(2.0 \mathrm{ml})$ and ammonia solution (15\%) to adjust $\mathrm{pH}$ to $7-8$. The precipitate was filtered off and washed with water (2.0 $\mathrm{ml})$. The resulting product $\mathbf{7} \mathbf{a}, \mathbf{b}$ was analytically pure and no additional purification was required.

2,2,2-Trifluoro-N' - [(1H-indolyl-3) methylene] - N-phenylacetylhydrazide (7a). Yield 55\%, m.p. $154-155^{\circ} \mathrm{C} .{ }^{1} \mathrm{H}$ NMR spectrum $\left(600 \mathrm{MHz}, \mathrm{DMSO}-d_{6}\right), \delta$, ppm: 7.34 t.t $\left(1 \mathrm{H}, J 7.5,1.0 \mathrm{~Hz}, \mathrm{H}_{p}\right), 7.39 \mathrm{~m}(1 \mathrm{H}$, $\left.\mathrm{H}^{6}\right), 7.43-7.46 \mathrm{~m}\left(2 \mathrm{H}, \mathrm{H}^{5}, \mathrm{H}^{6}\right), 7.54$ d.d $\left(2 \mathrm{H}, J\right.$ 8.6, $\left.7.5 \mathrm{~Hz}, \mathrm{H}_{m}\right), 7.70 \mathrm{~m}\left(1 \mathrm{H}, \mathrm{H}^{4}\right)$, 7.85 d.d $\left(2 \mathrm{H}, J\right.$ 8.6, $\left.1.0 \mathrm{~Hz}, \mathrm{H}_{z}, \mathrm{H}_{o}\right), 7.97$ s $\left(1 \mathrm{H}, \mathrm{H}^{1}\right), 8.78 \mathrm{~s}\left(1 \mathrm{H}, \mathrm{H}^{2}\right), 11.15 \mathrm{~s}(1 \mathrm{H}$, $\left.\mathrm{N}^{1} \mathrm{H}\right)$. 13C NMR spectrum (151 MHz, DMSO- $\left.d_{6}\right), \delta$, ppm: $116.08 \mathrm{q}\left(\mathrm{CF}_{3}, J 288.6\right.$ $\mathrm{Hz}), 118.22\left(\mathrm{C}_{o}\right), 120.64\left(\mathrm{C}^{3}\right), 126.19\left(\mathrm{C}^{2}\right)$, $126.49\left(C_{p}\right), 127.57\left(C^{6}\right), 128.18\left(C^{5}\right), 128.18$ $\left(C^{7}\right), 129.08\left(C^{4}\right), 129.64\left(C_{m}\right), 131.36\left(C^{7 a}\right)$, $139.39\left(\mathrm{C}_{i}\right), 139.7\left(\mathrm{C}^{1}\right), 155.52 \mathrm{q}(\mathrm{C}=\mathrm{O}, J$ $36.2 \mathrm{~Hz}) .{ }^{19} \mathrm{~F}$ NMR spectrum $(376 \mathrm{MHz}$, DMSO- $\left.d_{6}\right), \delta$, ppm: 74,52 (s, $\left.\mathrm{CF}_{3}\right) . \mathrm{MS}, \mathrm{m} / \mathrm{z}$ $\left(\mathrm{I}_{\mathrm{rel}}, \%\right): 331\left(\mathrm{M}^{+}, 100\right), 262(44)$.

2,2,2-Trifluoro-N' - [(2-methyl-1H-indolyl-3)methylene] - N-phenylacetylhydrazide (7b). Yield 64\%, m.p. 164$165{ }^{\circ} \mathrm{C} .{ }^{1} \mathrm{H}$ NMR spectrum $(500 \mathrm{MHz}$, DMSO- $\left.d_{6}\right), \delta$, ppm: $2.21 \mathrm{~s}\left(3 \mathrm{H}, \mathrm{CH}_{3}\right)$, 7.43-7.47 $\mathrm{m}\left(5 \mathrm{H}, \mathrm{H}^{4}, \mathrm{H}^{5}, \mathrm{H}^{6}, \mathrm{H}^{7}\right.$ and $\left.\mathrm{H}_{p}\right)$, 7.52 d.d $\left(2 \mathrm{H}, J\right.$ 8.5, $\left.1.4 \mathrm{~Hz}, \mathrm{H}_{o}\right), 7.57$ d.d $\left(2 \mathrm{H}, J\right.$ 8.5, $\left.7.2 \mathrm{~Hz}, \mathrm{H}_{m}\right), 7.63 \mathrm{~s}\left(1 \mathrm{H}, \mathrm{H}^{1^{\prime}}\right)$, $10.99 \mathrm{~s}\left(1 \mathrm{H}, \mathrm{N}^{1} \mathrm{H}\right) .{ }^{13} \mathrm{C}$ NMR spectrum (151 MHz, DMSO-d $d_{6}$ ), $\delta$, ppm: 115.98 q $\left(\mathrm{CF}_{3}, J 288.8 \mathrm{~Hz}\right), 118.04\left(\mathrm{C}^{3}\right), 124.4$ 
$\left(\mathrm{C}_{o}\right), 127.49\left(\mathrm{C}^{6}\right), 127.67\left(\mathrm{C}_{\mathrm{p}}\right), 127.76\left(\mathrm{C}^{5}\right)$, $127.78\left(\mathrm{C}^{7}\right), 129.27\left(\mathrm{C}_{m}\right), 130.99\left(\mathrm{C}^{4}\right)$, $136.06\left(C^{2}\right), 132.84\left(C^{7 \mathrm{7}}\right), 139.22\left(\mathrm{C}^{\mathrm{l}^{\prime}}\right)$, $139.44\left(\mathrm{C}_{i}\right), 155.28 \mathrm{q}(\mathrm{C}=\mathrm{O}, J 36.2 \mathrm{~Hz}) \cdot{ }^{19} \mathrm{~F}$
NMR spectrum $\left(376 \mathrm{MHz}, \mathrm{DMSO}-d_{6}\right), \delta$, ppm: $-74,45\left(\mathrm{~s}, \mathrm{CF}_{3}\right)$. MS, m/z $\left(\mathrm{I}_{\mathrm{rel}} \%\right)$ : $345\left(\mathrm{M}^{+} 80\right), 276(100)$.

\section{Results and discussion}

Arylhydrazones of indole-3-carbaldehydes $3 \mathbf{a}-\mathbf{e}$, which were obtained by heating indole-3-carbaldehydes 1a,b with phenylhydrazines $\mathbf{2 a - d}$ in ethanol with the addition of $\mathrm{HCl}$, were used as $\mathrm{C}$-nucleophiles for the studies (Scheme 1). It is known that the $E$-configuration of the $\mathrm{C}=\mathrm{N}$ bond is more thermodynamically favorable for arylhydrazones. This was confirmed by the data of X-ray structural analysis $[15,16]$.

We previously described that heating of quinazoline 4 with hydrazones 3a-c in TFA resulted in the formation of products 5a-c (Scheme 2) [14].
In current work, we have found that hydrazones 3d,e, which do not contain substituents in the phenyl fragment of the molecule, are added to quinazoline 4 at the $\mathrm{C}^{7}$ atom.

The reaction of quinazoline 4 with hydrazones $\mathbf{3 d}, \mathbf{e}$ in TFA yielded adducts $\mathbf{6 a}, \mathbf{b}$ (Scheme 3).

The mass spectra of compounds 6 contain molecular ions corresponding to the addition products of hydrazones 3d,e to quinazoline 4 . The mass spectra of compounds 6 contain molecular ions corresponding to the addition products of hydrazone to quinazoline. The ${ }^{1} \mathrm{H}$ NMR<smiles>[R]c1[nH]c2ccccc2c1C=O</smiles>

1a,b<smiles>[R]c1ccc(NN)cc1</smiles>

2a-d

\section{$\underset{\mathrm{HCl}}{\Delta, \mathrm{EtOH},}$}

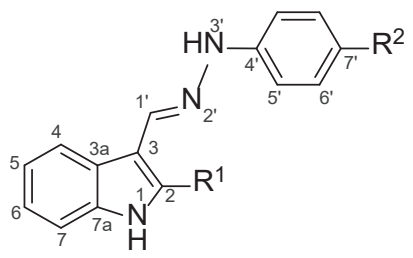

3a-e
1:

a: $\mathrm{R}^{1}=\mathrm{H}$

b: $R^{1}=M e$
2:

a: $\mathrm{R}^{2}=\mathrm{NO}_{2}$

b: $R^{2}=\mathrm{Me}$

c: $R^{2}=F$

d: $R^{2}=H$
3:

a: $R^{1}=M e ; R^{2}=N^{2}$

b: $R^{1}=M e ; R^{2}=M e$

c: $R^{1}=M e ; R^{2}=F$

d: $R^{1}=H ; R^{2}=H$

e: $R^{1}=M e ; R^{2}=H$

Scheme 1

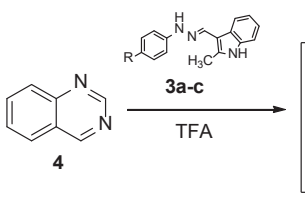

3,5: a R=NO, b R=CH,$c$ R=F

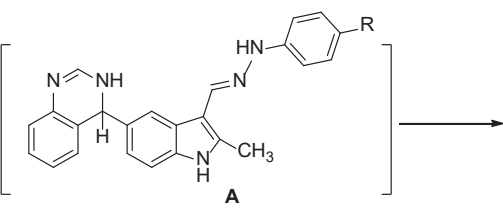

A

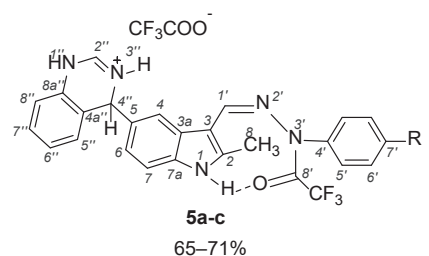

Scheme 2 


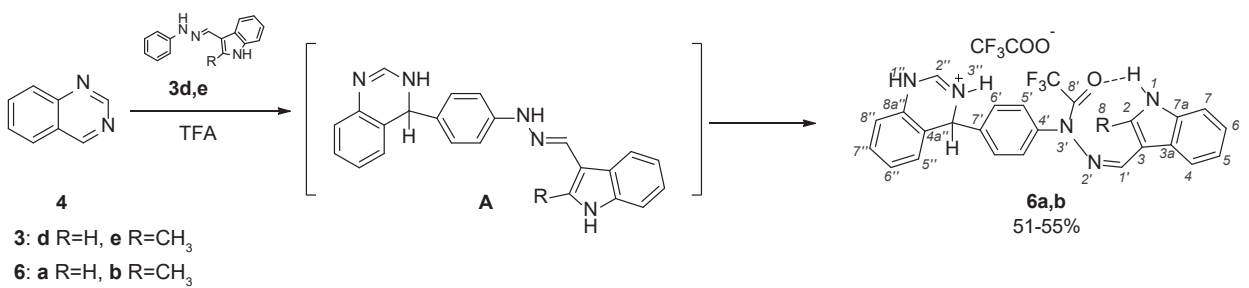

Scheme 3

spectrum contain characteristic signals: the $\mathrm{H} 4$ " proton singlet at $6.24 \mathrm{ppm}(\mathbf{6 a})$ and a pair of two-proton doublets of aromatic protons $\mathrm{H}^{6^{6}}, \mathrm{H}^{5^{5}}$ (7.61 and $7.92 \mathrm{ppm}$, respectively (6a)). These data confirm the addition of hydrazones $\mathbf{3 d}$,e to compound 4 by the $p$-position of the phenyl group. Since the signal of the NH-proton of the indole fragment is retained in adducts 6 , it is obvious that the hydrazine part of the molecule undergoes acylation.

It should be noted that the $2 \mathrm{D}{ }^{1} \mathrm{H}-{ }^{13} \mathrm{C}$ gHMBC spectra of adducts $\mathbf{6} \mathbf{a}, \mathbf{b}$ contain intense cross peaks between the characteristic quartet of C8' atom in the trifluoroacetyl group, in particular, at 155.9 ppm for compound $6 \mathrm{a}\left({ }^{2} \mathrm{~J}_{\mathrm{C}-\mathrm{F}}=36.3 \mathrm{~Hz}\right)$, and the broadened signal of the $\mathrm{N}^{1} \mathrm{H}$ proton (see Fig. 1), indicating the presence of an intramolecular hydrogen bond $\mathrm{N}-\mathrm{H} . . \mathrm{O}=\mathrm{C}$. Due to the presence of an intramolecular hydrogen bond in the molecule, it can be assumed that the $\mathrm{C}=\mathrm{N}$ bond of compounds $\mathbf{6 a}, \mathbf{b}$ in DMSO- $d_{6}$ has the $Z$ configuration, as in adducts $\mathbf{5}$.

We suggest that the formation of trifluoroacetyl derivatives of quinazoline $\mathbf{6}$, as well as adducts $\mathbf{5}$, occurs in several stages. Initially, the addition of hydrazone to quinazoline takes place, followed by acylation of the adduct with TFA at the $\mathrm{N}^{3} \mathrm{H}$-group with the formation of compounds 6 .

Since acylation of the NH group occurred during the C,C-coupling described above, we assumed that the same reaction would take place upon heating hydrazones 3 in TFA in the absence of quinazoline. This was confirmed in the course of experiments and hydrazides 7 were obtained (Sheme 4).

The structure of acylation products 7a,b was confirmed by ${ }^{1} \mathrm{H},{ }^{13} \mathrm{C},{ }^{15} \mathrm{~N}$, and

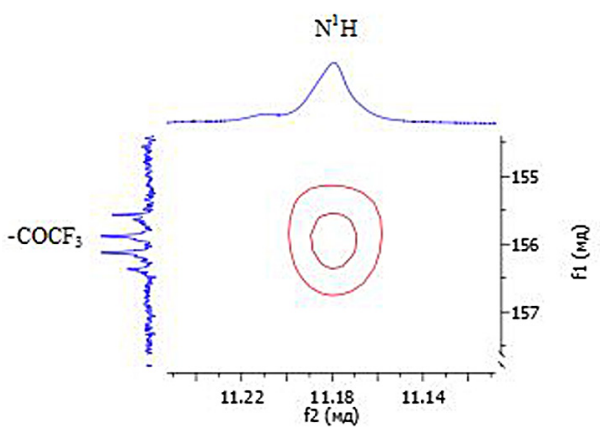

Fig. 1. Fragment of the NMR $2 \mathrm{D}{ }^{1} \mathrm{H}^{-13} \mathrm{C}$ $\mathrm{HMBC}$ spectrum for compound $\mathbf{6 a}$

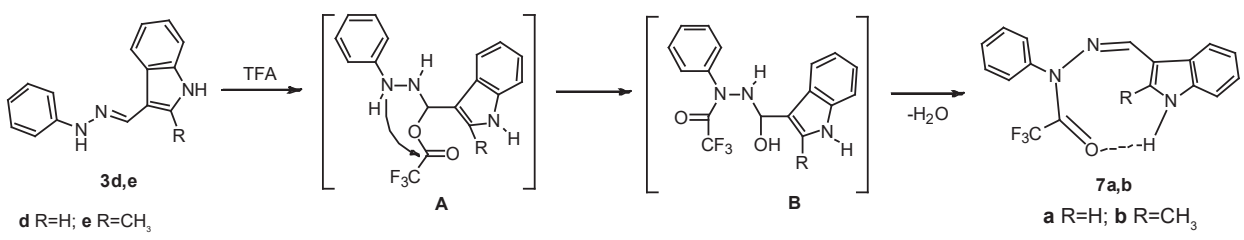

Scheme 4 


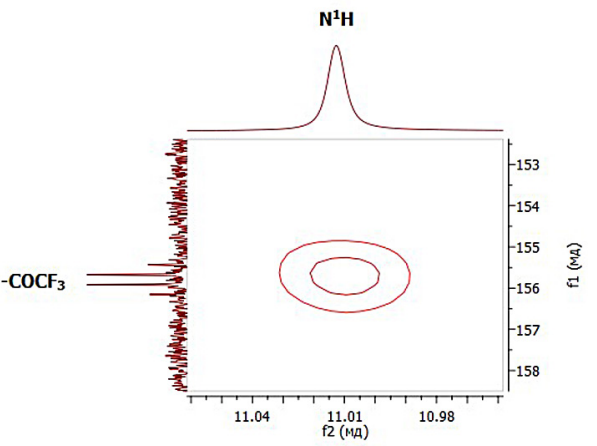

Fig. 2. Fragment of the NMR 2D 1H-13C

HMBC spectrum for compound 7

${ }^{19} \mathrm{~F}$ NMR spectroscopy including $2 \mathrm{D}^{1} \mathrm{H}^{13} \mathrm{C}$ HSQC / HMBC correlation experiments. Due to the fact, that the spectra of compounds $7 \mathbf{a}, \mathbf{b}$ contain signals of the $\mathrm{NH}$ protons of the indole fragment, it is obvious that the hydrazine part of the molecule undergoes acylation. $2 \mathrm{D}{ }^{1} \mathrm{H}-{ }^{13} \mathrm{C}$ HMBC spectra of compounds $7 \mathbf{a}, \mathbf{b}$ contain characteristic intense cross-peaks between the carbon quartet of the trifluoroacetyl group $\left(155.4 \mathrm{ppm},{ }^{2} \mathrm{~J}_{\mathrm{C}-\mathrm{F}}=36.7 \mathrm{~Hz}\right)$ and the $\mathrm{N}^{1} \mathrm{H}$ proton of the indole fragment (11.01 ppm). We believe that these cross peaks are due to the spin-spin interaction through the hydrogen bond (see Fig. 2).

It should be mentioned that the obtained hydrazides 7 do not react with quinazoline 4. Heating of quinazoline $\mathbf{4}$ with hydrazides $\mathbf{7 a}, \mathbf{b}$ in TFA gave the starting compounds 7 . The inertness of hydrazides 7 in the studied reactions of C,C-coupling confirms that the first stage of the multistep reaction is precisely the addition of the hydrazone 3 to the quinazoline 4 , and then the stage of acylation with acid occurs.

\section{Conclusions}

As a result of this work, it was found that the reactions of indole-3-carbaldehyde arylhydrazones with quinazoline can proceed either at 5- or 7' - position of the ar-

ylhydrazone molecule. It was shown that in the absence of substituents at both positions, the $\mathrm{C}^{7}$ atom is the most active nucleophilic center.

\section{Acknowledgements}

The authors are grateful to the Russian Foundation for Basic Research (grant 18-33-00727 mol_a) for financial support of the research.

\section{References}

1. D’yakonov AL, Telezhenetskaya MV. Quinazoline alkaloids in nature. Chem. Nat. Compd. 1997;33:221-267.

DOI: $10.1007 / \mathrm{BF} 02234869$

2. Aniszewski T. Alkaloids (Second Edition). Helsinki: Elsevier Science, 2015. 496 p.

3. Asif M. Chemical Characteristics, Synthetic Methods, and Biological Potential of Quinazoline and Quinazolinone Derivatives. Int. J. Med. Chem. 2014;ID 395637:1-27.

DOI: $10.1155 / 2014 / 395637$

4. Solyanik GI. Quinazoline compounds for antitumor treatment. Exp. Oncology. 2019;41:3-6.

DOI: 10.32471/exp-oncology.2312-8852.vol-41-no-1.12414

5. Tregubenko IP, Tarakhtii EA, Chibiriak MV, Golomolzin BV, Egorova LG. K voprosu o mekhanizme deystviya dialkilaminoetiltiol'nykh proizvodnykh pirimidina 
i khinazolina. Radiobiologiia. 1984;24:838-846. Russian. Available from: https:// elibrary.ru/item.asp?id $=25627353$

6. Pilicheva TL, Chupakhin ON, Postovsky IYa. Addition of nucleophiles to 3-methylquinazolinium iodide. Chem. Het. Comp. 1975;11:496-499.

DOI: $10.1007 / \mathrm{BF} 00502444$

7. Azev YuA, Shorshnev SV, Golomolzin BV. Specific features of the reactions of quinazoline and its 4-hydroxy and 4-chloro substituted derivatives with C-nucleophiles. Tetr. Lett. 2009;50:2899-2903.

DOI: 10.1016/j.tetlet.2009.03.199

8. Azev YuA, Koptyaeva OS, Seliverstova EA, Ivoilova AV, Pospelova TA. Synthesis of Stable $\sigma$-Adducts by Arylation of Quinazoline. Rus. J. Gen. Chem. 2019;89(12):2374-2377.

DOI: $10.1134 / S 1070363219120089$

9. Sundberg RJ. Indoles. San Diego: Academic Press Inc, 1996. 175 p.

10. Chadra N, Silakari O. Key Heterocycle Cores for Designing multitargeting molecules. Patiala: Elsevier, 2018, 285 p.

DOI: 10.1016/B978-0-08-102083-8.00008-X

11. Anastas PT, Warner JC. Green Chemistry Theory and Practice. New York: Oxford University Press, 1998, 516 p.

12. Charushin VN, Chupakhin ON. Topics in Heterocyclic Chemistry: Metal-free C-H functionalization of aromatic compounds through the action of nucleophilic reagents. Eds.: Charushin VN, Chupakhin ON. Switzerland: Springer; 2014;37:1-50.

13. Makosza M, Wojciechowski K. Topics in Heterocyclic Chemistry: Nucleophilic Substitution of Hydrogen in Arenes and Heteroarenes. Eds.: Charushin VN, Chupakhin ON. Switzerland: Springer; 2014;37:51-105.

14. Azev YuA, Koptyaeva OS, Eltzov OS, Yakovleva YuA, Pospelova TA, Bakulev VA. Quinazoline addition to indole hydrazone derivatives in TFA as a facile synthesis of trifluoroacetylhydrazide quinazoline $\sigma$-adducts. Mend. Comm. 2020;30:226-227. DOI: $10.1016 /$ j.mencom.2020.03.032

15. Zabaleta N, Uria U, Reyes E, Carrillo L, Vicario JL. Ion-pairing catalysis in the enantioselective addition of hydrazones to $\mathrm{N}$-acyldihydropyrrole derivatives. Chem. Comm. 2018;54:8905-8908.

DOI: $10.1039 / \mathrm{C} 8 \mathrm{CC} 05311 \mathrm{~A}$

16. Tung T, Tezcan H, San M, Bueykguengoer O, Yagbasan R. N-(4-Nitrobenzylidene) N'-phenylhydrazine. Acta Cryst., Sec. C. 2003;59:528-529.

DOI: $10.1107 /$ S0108270103016019 